\title{
PENELITIAN DAN PENGEMBANGAN SILABUS BAHASA INGGRIS PROGRAM STUDI PENERBITAN
}

\author{
Suratni \\ Program Studi Penerbitan, Jurusan Penerbitan, \\ Politeknik Negeri Media Kreatif Jakarta \\ Surel: ratni@polimedia.ac.id
}

\begin{abstract}
The development of research measures aim to (1) know the current syllabus; (2) get the data and conclusions about the syllabus; (3) find out theoretical syllabus developed nowadays; (4) draft and develop a new syllabus to suit the needs of students, faculty, and industry; (5) get the validity of the test results by getting experts to the syllabus; (6) get the limited field test results against the syllabus; (7) get the eligibility of the syllabus. There are two discussions in this research. First, an examination of the current English syllabus with study documents, learning, observation and analysis of the needs for the development of the syllabus. Second, the language syllabus development has been done by arranging the first prototype. Results of the tests on these students and lecturer next votes disqualified by experts. In this case, all three experts agree that the English syllabus in the third prototype is appropriate and valid to be implemented in PoliMedia.
\end{abstract}

Key words: research and development, English syllabus, publishing

\section{PENDAHULUAN}

Proses pembelajaran bahasa Inggris yang banyak dipraktikkan oleh para dosen saat ini sebagian besar berbentuk penyampaian secara tatap muka yang searah (one way communication). Dengan proses yang demikian, pada saat mengikuti kuliah atau mendengarkan ceramah, mahasiswa akan kesulitan untuk mengikuti atau menangkap makna esensi materi pembelajaran sehingga aktivitas mahasiswa hanya didominasi dengan membuat catatan/rangkuman materi. Pada akhirnya, metode pembelajaran dengan dosen aktif dan mahasiswa pasif ini efektifitasnya rendah dan tidak dapat membangun partisipasi mahasiswa untuk aktif dalam pembelajaran. Keadaan ini terjadi sebagai akibat elemen-elemen terbentuknya proses partisipasi tidak ada atau sangat terbatas. Adapun elemen proses pembentuk partisipasi antara lain adanya dorongan untuk memperoleh harapan (effort), kemampuan mengikuti proses pembelajaran, dan peluang untuk mengungkapkan materi pembelajaran yang diperolehnya di masyarakat. Intensitas pembelajaran mahasiswa umumnya meningkat 
(tetapi tetap tidak efektif), terjadi pada saat-saat akhir mendekati ujian, dengan istilah populer SKS (Sistem Kebut Semalam). Akibatnya mutu materi dan proses pembelajaran sangat sulit untuk dinilai keberhasilannya.

Dalam pembelajaran bahasa Inggris, terkadang dosen menjadi dirinya pusat peran dalam pencapaian hasil pembelajaran dan seakan-akan menjadi satu-satunya sumber ilmu. Bahwa dosen dianggap sebagai sosok penutur yang paling menguasai bahasa Inggris baik lisan dan tertulis. Namun, anggapan seperti ini pun tidak dibenarkan. Perbaikan pola pembelajaran ini telah banyak dilakukan dengan kombinasi lecturing, tanya-jawab, dan pemberian tugas, yang kesemuanya dilakukan berdasarkan "pengalaman mengajar" dosen yang bersangkutan dan bersifat trial-error. Luaran proses pembelajaran tetap tidak dapat dinilai, serta memerlukan waktu lama pelaksanaan perbaikannya.

Pola pembelajaran di perguruan tinggi yang berlangsung saat sekarang perlu dikaji untuk dapat dipetakan pola keragamannya. Oleh karenanya perlu dilakukan perubahan dalam proses dan materi pembelajaran di perguruan tinggi tidak lagi berbentuk TeacherCentered Content-Oriented (TCCO), tetapi diganti dengan menggunakan prinsip Student-Centered Learning (SCL) yang disesuaikan dengan keadaan perguruan tingginya.
Perubahan dalam hal proses dan materi pembelajaran di perguruan tinggi khususnya di politeknik dapat dilakukan dengan pengembangan silabus mata kuliah yang merupakan salah satu aspek dari penyelenggaraan program pendidikan. Silabus mata kuliah berhubungan dengan upaya-upaya penyediaan dan pengadaan pedoman atau panduan bagi dosen untuk melaksanakan pengajaran dan pembelajaran, baik di dalam kelas maupun di luar kelas, supaya tujuan yang telah ditetapkan dapat terwujud. Upaya-upaya tersebut dapat dilakukan oleh beberapa pihak, seperti dosen baik secara individual maupun kelompok, lembagalembaga penyelenggara program pendidikan, atau pemerintah.

Berkaitan dengan pengembangan silabus mata kuliah di politeknik, peneliti sebagai dosen bahasa Inggris pada Program Studi Penerbitan tertarik untuk melakukan penelitian terhadap silabus bahasa Inggris yang digunakan pada Program Studi Penerbitan. Silabus ini telah digunakan selama 5 (lima) tahun sejak berdirinya Politeknik Negeri Media Kreatif pada 2009. Berdasarkan hasil penelitian tersebut, peneliti selanjutnya melakukan pengembangan silabus untuk merumuskan usulan silabus baru yang up to date dan didesain agar sesuai dengan kebutuhan mahasiswa, dosen, dan dunia industri.

Tujuan penelitian ini dapat dicapai dengan penelitian pengembangan. Secara khusus, 
tujuan penelitian dirinci menjadi 7 (tujuh) tujuan yang sejalan dengan prosedur penelitian pengembangan. Langkah pengembangan tersebut bertujuan untuk

1) mengetahui silabus mata kuliah bahasa Inggris yang sedang berjalan;

2) mendapatkan data dan simpulan tentang silabus mata kuliah bahasa Inggris yang sesuai dengan kebutuhan mahasiswa, dosen, dan industri;

3) mengetahui silabus teoretis yang berkembang dewasa ini;

4) menyusun dan mengembangkan silabus mata kuliah bahasa Inggris yang sesuai dengan kebutuhan mahasiswa, dosen, dan industri;

5) mendapatkan hasil uji validitas oleh pakar terhadap silabus mata kuliah bahasa Inggris;

6) mendapatkan hasil uji lapangan terbatas terhadap silabus mata kuliah bahasa Inggris; dan

7) mendapatkan hasil uji kelayakan terhadap silabus pembelajaran mata kuliah Inggris.

Mc Kay, sebagaimana dikutip dalam Furey (1983:3) berpendapat bahwa silabus secara mendasar berkaitan dengan apa yang dipelajari. Nunan (1989:14) menyatakan bahwa silabus berkaitan dengan penyeleksian dan pengurutan isi. Sementara Brown (2005:5) menyatakan bahwa Syllabus is ways of organizing the course and materials. Lebih jauh Wilkins menyatakan bahwa silabus merupakan spesifikasi isi pengajaran bahasa yang telah diseleksi dan disusun berdasarkan jenjangnya dengan tujuan membuat proses belajar mengajar menjadi lebih efektif (dikutip dalam Furey, 1983:3 - 4). Berdasarkan beberapa pendapat tentang silabus tersebut, peneliti dapat menyimpulkan bahwa silabus pada dasarnya memuat konsep apa yang dipelajari, cara memilah-milahnya, cara menyusunnya, dan cara mengajarkannya.

Harmer dalam bukunya The

Practice of English Language Teaching (2011:295) mengungkapkan beberapa kriteria yang harus dipertimbangkan sebagai dasar penyusunan desain silabus. Kriteria-kriteria tersebut antara lain learnability, frecuency, coverage, dan usefulness. (1) Kemampuan belajar (Learnability) berkaitan dengan mudah atau tidaknya struktur dan butir-butir leksikal tertentu dipelajari oleh siswa. (2) Frekuensi berkaitan dengan butir-butir bahasa yang banyak digunakan dalam penggunaan dan butir-butir yang jarang digunakan dalam berbahasa. (3) Pencakupan (Coverage) terkait dengan beberapa kata dan struktur gramatikal meliputi cakupan penggunaan yang lebih besar daripada kata dan struktur gramatikal lainnya. (4) Kebermanfaatannya (Usefulness) berkaitan dengan apakah butir-butir leksikal tertentu lebih dekat dengan kehidupan siswa sehingga lebih bermanfaat bagi siswa jika digunakan di kelas. 
Analisis kebutuhan (needs analysis atau needs assessment) mengacu kepada semua kegiatan yang dilakukan dalam rangka pengumpulan informasi yang akan digunakan sebagai dasar bagi pengembangan silabus (Brown, 2005:35). Analisis kebutuhan siswa inilah yang menjadi hal penting dalam pengembangan silabus (Cunningsworth, 1995:38). Sebagaimana juga dikemukakan oleh Munby (1981:3) “... the syllabus and materials are determined in all essentials by the prior analysis of the communication needs of the learner.

Dalam buku Principles and Methods of Development Research (2009), Akker menyatakan ada 4 (empat) tahap dalam penelitian pengembangan. Keempat tahapan tersebut adalah preliminary investigation, theoretical embedding, empirical testing, dan documentation, analysis, and reflection on process and outcome. Berikut penjelasan masing-masing tahapan.

(1) Pemeriksaan pendahuluan, pemeriksaan pendahuluan yang sistematis dan intensif dari permasalahan mencakup: tinjauan ulang literatur, konsultasi tenaga ahli, analisis tentang ketersediaan contoh untuk tujuan yang terkait, dan studi kasus dari praktik yang umum untuk merincikan kebutuhan.

(2) Penyesuaian teoritis, usaha yang lebih sistematis dibuat untuk menerapkan dasar pengetahuan dalam mengutarakan dasar pemikiran yang teoritis untuk pilihan rancangan.

(3) Uji empiris, bukti empiris yang jelas menunjukkan tentang kepraktisan dan efektivitas dari intervensi.

(4) Proses dan hasil dokumentasi, analisis dan refleksi, implementasi dan hasilnya untuk berperan pada spesifikasi dan perluasan metodologi rancangan dan pengembangan penelitian.

\section{METODE PENELITIAN}

$\begin{array}{llr}\text { Penelitian } & \text { tentang } \\ \text { pengembangan } & \text { silabus } & \text { bahasa } \\ \text { Inggris untuk } & \text { Program Studi }\end{array}$
Penerbitan Politeknik Negeri Media Kreatif ini menggunakan metode penelitian pengembangan melalui tujuh tahapan penelitian yang dikembangkan oleh David Jolly dan Rod Bolitho dalam Nurhayati (2008:97-99). Untuk mendapatkan hasil penelitian yang tepat guna, peneliti menyederhanakan ketujuh tahapan tersebut sesuai kebutuhan penelitian pengembangan silabus. Dengan demikian, langkah penelitiannya terdiri atas dua tahapan utama sebagai berikut.

(1) Penelitian terhadap silabus bahasa Inggris yang sedang berjalan dengan studi dokumen, observasi pembelajaran, dan analisis kebutuhan untuk pengembangan silabus.

(2) Pengembangan silabus pembelajaran bahasa Inggris pada Program Studi Penerbitan, 
dilakukan dengan tahapan sebagai berikut.

a. Penyusunan draf silabus berdasarkan hasil studi dokumen, observasi, dan analisis kebutuhan. Silabus ini disebut prototipe pertama.

b. Prototipe pertama ini divalidasi dengan metode peer review. Peneliti melibatkan 5 (lima) teman sejawat, yaitu Ari Budiani, Herlinda Simanjuntak, Heni Suprihatin, Ratna Puspita, dan Ahmad Guntawan. Kelima teman sejawat tersebut merupakan dosan bahasa Inggris yang memberi saran dan masukan untuk perbaikan prototipe pertama ini. Hasil perbaikan terhadap prototipe pertama ini disebut prototipe kedua.

c. Validasi prototipe kedua dilakukan dengan melibatkan 2 (dua) pakar (expert review), Ibu Redjeki Agoestyaswati sebagai dosen bahasa Inggris pada salah satu perguruan tinggi swasta di Jakarta dan penulis buku pada PT Grasindo dan Ibu Fariah, dosen bahasa Inggris, penulis berbagai buku dalam bahasa Inggris, dan narasumber nasional untuk pelatihan bahasa Inggris bagi pendidik. Kedua pakar tersebut peneliti pandang sebagai narasumber yang tepat karena keduanya menguasai konten bahasa Inggris, memahami proses pembelajaran di kelas, dan keduanya pernah menghasilkan produk pembelajaran bahasa Inggris. Hasil perbaikan terhadap prototipe kedua disebut prototipe ketiga.

d. Prototipe ketiga ini selanjutnya diujicobakan pada salah satu dosen bahasa Inggris, yaitu Ibu Herlinda Simanjuntak untuk menyusun rencana pelaksanaan pembelajaran (RPP) dari salah satu materi pada silabus prototipe ketiga tersebut. Prototipe ketiga ini juga diujicobakan pada salah satu kelas di Program Studi Penerbitan, Juni 2014. Materi yang dipilih adalah Writing Creative Curriculum Vitae pada mahasiswa semester IV.

e. Hasil ujicoba pada dosen dan mahasiswa ini selanjutnya dinilai kelayakannya oleh pakar. Dalam hal ini, selain menggunakan analisis kedua pakar sebelumnya, peneliti juga meminta bantuan Bapak Dion Sitanggang selaku Manajer Produksi PT Ganesha Exact.

\section{HASIL DAN PEMBAHASAN}

\section{Hasil Penelitian}

Pada bagian ini, peneliti menjelaskan dua pokok bahasan, yaitu hasil penelitian dan pengembangan silabus. Pertama, penjabaran tentang hasil penelitian mencakup studi dokumen yang 
terkait dengan silabus yang sedang berjalan, observasi terhadap pelaksanaan pembelajaran bahasa Inggris dengan silabus sekarang, analisis kebutuhan, dan hasil penelitian. Kedua, penjabaran tentang pengembangan silabus mencakup penyusunan prototipe pertama dan prototipe kedua.

Prototipe pertama divalidasi dengan metode peer review sedangkan prototipe kedua divalidasi dengan metode expert review. Selanjutnya, dengan hasil expert review, peneliti menyusun prototipe ketiga. Prototipe ketiga diujicobakan pada satu dosen bahasa Inggris dan satu kali tatap muka pembelajaran di kelas. Pada bagian ini, peneliti menjelaskan hasil studi dokumen, observasi kelas, dan angket serta wawancara untuk mendapatkan gambaran analisis kebutuhan mahasiswa, dosen, dan dunia industri terhadap pembelajaran bahasa Inggris.

\section{Studi Dokumen}

Dari hasil studi dokumen terhadap silabus bahasa Inggris yang digunakan di Program Studi Penerbitan pada Tahun Akademik 2013/2014 ditemukan bahwa silabus yang digunakan adalah silabus yang disusun salah satu dosen bahasa Inggris pada Program Studi Penerbitan, yaitu bapak Drs. Zalzulifa, M.Pd. Hingga saat ini, silabus tersebut telah diterapkan selama 5 (lima) tahun. Unsur-unsur silabus tersebut mencakup identity (identitas pembelajaran bahasa
Inggris), standard competencies (kompetensi standar), competencies to be achieved (kompetensi dasar pembelajaran yang ingin dicapai), subjects (materi pembelajaran), teaching methodology (metode pembelajaran), value indicator (indikator pembelajaran), scores (penilaian), dan references (daftar rujukan).

\section{a. Identitas Silabus}

Identitas silabus pembelajaran bahasa Inggris adalah sebagai berikut.

1) Nama mata kuliah yaitu: Bahasa Inggris 1, 2, 3, dan 4

2) Program Studi: Penerbitan

3) Dosen: Drs. Zalzulifa, M.Pd.

4) Semester dan Tahun Akademik: Semester Ganjil-Genap TA 2013/2014

5) Kode Mata Kuliah: MPK3104 (Bahasa Inggris)

PNB3107

(Bahasa Inggris 2)

PNB3117 (Bahasa Inggris 3)

$$
\text { PNB3124 (Bahasa }
$$

Inggris 4)

6) Jumlah SKS dan Jam Kuliah: 2 / 38 jam

\section{b. Standar Kompetensi}

Bahasa Inggris yang digunakan di Program Studi Penerbitan merupakan bahasa Inggris untuk Bidang Kekhususan Penerbitan (English for Specific Purpose). Adapun standar kompetensi pembelajaran bahasa Inggris untuk Program Studi Penerbitan untuk 4 (empat) semester adalah sebagai berikut.

Semester I 
At the end of lecture, the students are expected to know sixteen basic tenses and understand how should mechanics (apostrophes, dash, question marks, exclamation, comma, full stop) be used? The students will also learn about the verb, relative, adverbial and noun concepts, what's the difference between 'which' and 'that', etc?

\section{Semester II}

At the end of lecture, the students are expected to know various kinds of writing styles or manuscripts shown by the ability of speaking, writing, editing, listening, interpreting, and presenting

Semester III

At the end of lecture, the students are expected to know various kinds of activities related to the publishing industries (Editorial; commissioning and acquisitions, right, and contracts) shown by the ability of speaking, writing, editing, listening, interpreting, and presenting in English language.

\section{Semester IV}

At the end of lecture, the students are expected to know the language used in creative publications shown by the ability of speaking, writing, editing, listening, interpreting, and presenting in English language.

\section{c. Kompetensi Dasar}

Hasil studi dokumen terhadap silabus yang sedang berjalan memberi informasi kompetensi dasar yang ingin dicapai telah disesuaikan dengan standar kompetensi yang telah ditetapkan. Kompetensi dasar tersebut ditekankan pada kemampuan mahasiswa untuk memahami bidang: sixteen basic tenses and mechanics (Semester I), various kinds of writing styles or manuscripts (Semester II), various kinds of activities related to the publishing industries (Semester III), dan the language used in creative publications (Semester IV)

\section{d. Materi dan Metode \\ Pembelajaran}

Berdasarkan hasil studi dokumen terhadap silabus yang sedang berjalan, berikut rangkuman materi perminggu, sebanyak 4 (empat) semester.Dari hasil studi dokumen terhadap dokumen silabus yang sedang berjalan diketahui bahwa metode yang terdapat dalam silabus ialah Brainstorming, Discussion, Interpreting, Listening, Negotiating, Presenting, Self-access, Simulation, Speaking, Speech, Translating, dan Writing. Dengan demikian, metode pembelajaran yang terdapat di dalam silabus berjalan ialah metode gabungan.

\section{e. Indikator Pembelajaran}

Berdasarkan hasil studi dokumen terhadap silabus berjalan diketahui bahwa teknik pembelajaran yang terdapat di silabus ialah teknik yang membuat mahasiswa aktif belajar dengan kegiatan mendengarkan, membaca, menulis, dan diskusi. 


\section{f. Penilaian Hasil Belajar dan Silabus Pembelajaran Bahasa \\ Inggris yang sedang Berjalan}

Studi dokumen terhadap silabus menunjukkan bahwa teknik penilaian hasil belajar dilakukan dengan teknik tes tulis, tes unjuk kerja, tes penugasan, tes lisan, portofolio, dan observasi. Berdasarkan hasil analisis dokumen dan wawancara dengan Dosen didapati bahwa silabus pembelajaran bahasa Inggris yang sedang berjalan adalah silabus yang ditetapkan oleh Politeknik Negeri Media Kreatif tahun 2013.

\section{g. Hasil Belajar Mahasiswa dengan Silabus yang sedang Berjalan}

Tabel 1 merupakan rangkuman nilai belajar bahasa Inggris untuk Angkatan 5 dan 6 Mahasiswa Penerbitan Politeknik Negeri Media
Kreatif. Untuk mahasiswa Angkatan 5, mereka telah menyelesaikan pembelajaran bahasa Inggris selama 4 (empat) semester. Namun, untuk Angkatan 6, mereka baru menempuh Semester I dan Semester II. Hasil belajar dengan menggunakan silabus yang sedang berjalan pada Angkatan ke-5 Kelas A adalah "Baik" untuk Semester I-III dan "Lebih Dari Baik" untuk Semester IV. Untuk Kelas 1B, "Cukup Baik" pada Semester I dan "Baik" pada Semester II dan III, serta mengalami kenaikan ke level "Lebih Dari Baik" Semester IV. Mahasiswa Angkatan ke-6 mendapatkan hasil belajar "Baik" untuk Kelas 1A dan 1C, "Cukup Baik" untuk Kelas 1B. Namun demikian, untuk Semester II, mereka mendapatkan nilai "Baik".

Tabel 1 Rerata Nilai Bahasa Inggris Angkatan 5 dan 6 Prodi Penerbitan

\begin{tabular}{ccccccc}
\hline Angkatan & Kelas & $\begin{array}{c}\text { Jumlah } \\
\text { Mahasiswa }\end{array}$ & $\begin{array}{c}\text { Semester I } \\
\text { TA 2012 }\end{array}$ & $\begin{array}{c}\text { Semester II } \\
\text { TA 2012 }\end{array}$ & $\begin{array}{c}\text { Semester } \\
\text { III } \\
\text { TA 2013 }\end{array}$ & $\begin{array}{c}\text { Semester } \\
\text { IV } \\
\text { TA 2013 }\end{array}$ \\
\hline $\mathbf{5}$ & & & & 71.37 & 74 & 76 \\
$\mathbf{5}$ & A & 28 & 71 & 70.19 & 72 & 75 \\
Angkatan & Kelas & Jumlah & & & Semester I & Semester II \\
& & Mahasiswa & & & TA 2013 & TA 2013 \\
$\mathbf{6}$ & A & 26 & & & 70 & 71.48 \\
$\mathbf{6}$ & B & 27 & & & 71 & 71.39 \\
$\mathbf{6}$ & C & 25 & & & & 74.6 \\
\hline
\end{tabular}

\section{Observasi terhadap Pelaksanaan Pembelajaran Bahasa Inggris}

Berikut merupakan hasil observasi peneliti selama bulan April-Mei $2014 \quad$ terhadap pelaksanaan pembelajaran bahasa Inggris dengan menggunakan silabus yang sedang berjalan. Peneliti telah mengobservasi kelas Penerbitan Semester II dan Semester IV. Di dalam pelaksanaan pembelajaran menulis, dosen melakukan kegiatan (1) membuka laptop dan menayangkan PowerPoint tentang 
Travel Writing for Newspapers and Magazines; (2) menghubungkan materi lama yang berkaitan dengan kegiatan yang akan dilakukan, (3) meminta mahasiswa membaca modul pada halaman tertentu yang memberikan contoh laporan perjalanan, (4) menjelaskan secara umum cara membuat kerangka karangan laporan, (5) meminta mahasiswa memberi contoh pembukaan laporan berdasarkan urutan ruang secara lisan, (6) meminta mahasiswa secara bergiliran menulis di papan tulis contoh kerangka karangan berdasarkan pola $5 \mathrm{~W}+1 \mathrm{H}$, (7) meminta mahasiswa membuat laporan perjalanan secara utuh berdasarkan kerangka karangan yang telah disusun, (8) melihat mahasiswa menulis dengan berkeliling kelas.

\section{Analisis Kebutuhan}

\section{a. Analisis Kebutuhan Dosen}

Berikut dikemukakan hasil
analisis kebutuhan dosen
pembelajaran bahasa Inggris di Politeknik Negeri Media Kreatif yang diperoleh dari angket. Menurut Responden Dosen, silabus yang sedang berjalan ini sudah memenuhi unsur-unsur silabus yang baik. Namun, seiring berjalannya waktu, silabus tersebut perlu dievaluasi dan diupdate sesuai dengan perkembangan dunia pendidikan dan tuntutan dunia industri penerbitan. Hal-hal yang perlu digarisbawahi adalah jumlah materi seharusnya disesuaikan karena materi pada silabus yang sedang berjalan ini hanya untuk 14 pertemuan. Sedangkan, jumlah pertemuan yang diterapkan saat ini adalah 16. Kedua, silabus berjalan belum sepenuhnya menerapkan Student Center Learner (SCL). Konten materi perlu disesuaikan lagi dengan menghilangkan dan menambahkan beberapa materi pembelajaran. Selanjutnya, materi Creative Curriculum Vitae dan Job Interview perlu ditambahkan di Semester IV. Terkait dengan indikator pencapaian kompetensi, kelima responden sepakat bahwa aspek yang digunakan dalam silabus bahasa Inggris adalah aspek kognitif, afektif, dan motorik.

Untuk materi pembelajaran, para Responden Dosen sepakat bahwa materi pada Semester I masih General English. Empat Responden Dosen memiliki usulan yang sama bahwa pada Semester II, materi pembelajaran bahasa Inggris mulai dikaitkan dengan bidang penerbitan. Hanya ada satu Responden Dosen yang ini memantapkan kemampuan berbicara mahasiswa pada Semester II. Semua Responden menempatkan materi kekhususan penerbitan di Semester III dan IV. Di Semester IV mengkhususkan ke Business English yang terkait dengan bidang penerbitan.

Empat dari lima Responden menyatakan bahwa materi pada Semester III dan IV pada silabus yang berjalan terlalu berat untuk level Diploma III. Menurut mereka, materi yang sebaiknya disampaikan kepada mahasiswa dapat berupa terminologi bidang penerbitan, 
teknik presentasi, etika dan bahasa dalam berbisnis, karier di industri penerbitan, menulis lamaran pekerjaan dan CV yang kreatif, serta praktik wawancara pekerjaan.

Penilaian Responden Dosen menunjukkan bahwa mereka menyatakan belum ada pendekatan pembelajaran yang terdapat di dalam silabus yang sedang berjalan. Selama pembelajaran, Responden mengakui menggunakan perpaduan pendekatan struktural, komunikatif, apresiatif, dan pragmatik. Pendekatan struktural digunakan sebagai panduan runtutan materi yang disampaikan. Pendekatan komunikatif untuk menghidupkan suasana kelas. Pendekatan apresiatif digunakan untuk memberikan penghargaan atas pencapaian mahasiswa. Sedangkan, pendekatan pragmatik untuk pengembangan softskill mahasiswa khususnya yang terkait dengan bahasa Inggris. Sebagian Responden Dosen setuju dengan fokus pembelajaran pada aspek lisan dan tulisan ragam formal. Namun, tidak ada salahnya jika silabus bahasa Inggris terdapat bahasa ragam nonformal.

$$
\text { Presentase penilaian mata }
$$

kuliah bahasa Inggris: Kehadiran $10 \%$, UTS $15 \%$, UAS $35 \%$, dan Tugas $40 \%$. Nilai tugas mendapatkan persentase paling tinggi dengan alasan bahwa pendidikan politeknik menerapkan product-based activity. Nilai tugas juga dapat diperinci sesuai dengan kebutuhan pembelajaran, misalnya nilai keaktifan di kelas, tugas mandiri, dan projek akhir.

\section{b. Analisis Kebutuhan Mahasiswa}

Berikut data analisis kebutuhan mahasiswa yang diperoleh melalui angket dan wawancara. Hasil angket menunjukkan bahwa $63 \%$ mahasiswa suka terhadap pelajaran bahasa Inggris dan mereka memperhatikan pembelajaran bahasa Inggris (90\%). Sejumlah $60 \%$ mahasiswa berpendapat bahwa pembelajaran bahasa Inggris mudah dan 40\% mahasiswa menyatakan bahwa pembelajaran bahasa Inggris sulit. Dari wawancara diketahui bahwa yang menyebabkan mahasiswa menganggap pembelajaran bahasa Inggris sulit ialah terutama pada aspek berbicara.

Sementara itu, $\quad 100 \%$ mahasiswa setuju bahwa tujuan pembelajaran bahasa Inggris di Politeknik adalah agar mahasiswa memiliki keterampilan berbahasa yang meliputi aspek mendengarkan, berbicara, membaca, dan menulis hubungannya dengan bidang penerbitan. Kemampuan tambahan yang ingin mereka kuasai adalah menulis dan menyunting teks berbahasa Inggris serta berkomunikasi dengan dunia industri. Hal ini diperlihatkan dengan tingginya persentase mahasiswa yang menyatakan bahwa mereka memerlukan sekali tentang pengetahuan bahasa Inggris itu yakni $90 \%$. Sehubungan dengan metode mengajar yang dipakai oleh Dosen Bahasa Inggris, seluruh mahasiswa 
(100\%) berpendapat bahwa metode mengajar dosen menekankan keaktifan mahasiswa dalam belajar sedangkan dosen membimbing. Mengenai, produk akhir dari pembelajaran bahasa Inggris, sebanyak $80 \%$ responden mahasiswa belum memiliki portofolio bahasa Inggris.

\section{c. Analisis Kebutuhan Industri}

Ketiga Responden sepakat bahwa lulusan DIII Penerbitan PoliMedia memiliki prospek kerja yang bagus di industri penerbitan. Pertama, lulusan DIII Penerbitan memiliki kemampuan mengedit dan menguasai simbol-simbol editing. Hal ini merupakan nilai tambah ketimbang lulusan program studi lain. Kedua, selain kemampuan menulis dan mengedit, mereka juga dibekali ilmu layout dan pemasaran. Hal ini merupakan paket komplit untuk pekerja di indutri penerbitan. Sayangnya level Diploma III yang dinilai belum memenuhi jika ingin berkarier sebagai editor.

Dari item pertanyaan untuk Responden Industri tentang kemampuan berbahasa, terlihat jelas bahwa kemampuan berbahasa Inggris sangat dibutuhkan bagi calon karyawan di penerbit. Pada tahapan awal, kemampuan berbahasa Inggris yang dinilai adalah pada penulisan surat lamaran dan daftar riwayat hidup (CV) serta kemampuan lisan pada proses interview. Untuk itulah, materi penulisan surat lamaran dan $\mathrm{CV}$ serta interview pekerjaan harus dimasukkan ke silabus yang baru.
Terkait dengan kemampuan dasar yang dibutuhkan, responden memberikan gambaran bahwa calon karyawan minimal harus bisa percakapan sehari-hari, menguasai istilah-istilah dan teks berbahasa Inggris. Responden 3 menambahkan bahwa memiliki kemampuan menulis dan menanggapi surat dalam bahasa Inggris juga menjadi nilai lebih.

\section{Temuan Penelitian}

Dari hasil studi dokumen, terlihat bahwa penamaan mata kuliah bahasa Inggris selama 4 (empat) semester tersebut menggunakan istilah Bahasa Inggris 1, 2, 3, dan 4. Hal ini belum sesuai dengan aturan yang telah ditetapkan oleh Direktur Jendral Pendidikan Tinggi. Mata kuliah tersebut juga belum memiliki deskripsi mata kuliah persemesternya. Kompetensi standar yang sudah mengacu pada bahasa Inggris kekhususan bidang penerbitan, tetapi ada standar yang sebaiknya disesuaikan lagi. Selanjutnya mengenai jumlah materi pembelajaran, hanya ada 14 minggu. Sebaiknya disesuaikan menjadi 16 minggu. Materi pada semester III dan IV tingkatan terlalu sulit untuk level politeknik. Berdasarkan data yang diperoleh dari observasi silabus yang sedang berjalan dan observasi proses pembelajaran dengan silabus yang sedang berjalan, serta analisis kebutuhan dapat dikemukakan adanya kesenjangan antara harapan dan kenyataan.

Berdasarkan hasil wawancara dan angket tertulis terhadap 
mahasiswa, mahasiswa menilai materi pada silabus sekarang cukup sulit untuk mereka ikuti. Harapan mereka, mendapatkan pembelajaran bahasa Inggris yang lebih informatif dan aplikatif untuk mendukung kemampuan berbahasanya. Sedangkan berdasarkan data angket terhadap dosen, kelima teman sejawat peneliti sependapat bahwa silabus yang sedang berjalan perlu diupdate sesuai dengan kebutuhan sekarang, mengingat silabus ini sudah 5 (lima) tahun digunakan.

Berdasarkan hasil analisis kebutuhan dosen, bagian yang paling penting untuk segera disesuaikan adalah materi pembelajaran selama 4 (empat) semester tersebut. Pada semester III dan IV, berdasarkan penuturan Responden Dosen, materinya terlalu tinggi untuk level Diploma III. Selain penyesuaian jumlah materi dan pokok bahasannya, ada beberapa hal yang juga harus disesuaikan, yaitu tujuan pembelajaran bahasa Inggris, metodologi yang meliputi pendekatan dan metode serta sumber belajar, dan penilaian.

Sedangkan berdasarkan hasil analisis kebutuhan industri, materi yang perlu diajarkan untuk mahasiswa Program Studi Penerbitan antara lain menulis surat menyurat, di dalamnya surat lamaran dan CV, menulis dan menyunting teks dalam bahasa Inggris, mahir dalam menggunakan tanda baca dan huruf kapital, dan fasih dalam percakapan sehari-hari dan percakapan dalam berbisnis.

\section{Pengembangan Silabus}

Pengembangan silabus bahasa Inggris disusun dengan skema di bawah ini. Di dalamnya, terdapat uji lapangan terbatas menggunakan prototipe III oleh dosen dan satu kali pembelajaran di kelas. Selanjutnya, dilakukan uji validitas dan uji kelayakan silabus yang baru oleh pakar.

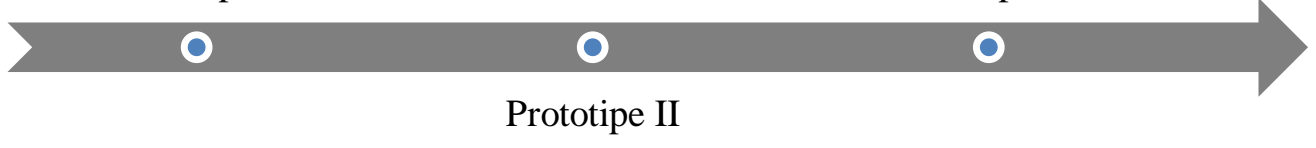

Gambar 1 Skema Pengembangan Silabus

\section{Prototipe I}

Berdasarkan hasil observasi terhadap silabus yang sedang berjalan, analisis kebutuhan, dan kajian teoretik, peneliti membuat rancangan silabus pembelajaran bahasa Inggris untuk Program Studi Penerbitan di PoliMedia. Rancangan silabus tersebut mengarah kepada pengembangan silabus campuran. Dengan desain silabus campuran kekurangan yang dimiliki desain silabus tertentu akan ditutupi oleh desain silabus lainnya.

Oleh sebab itu, silabus yang dikembangkan bersifat eklektik yang 
memadukan pendekatan-pendekatan desain silabus yang tersedia untuk menjamin mahasiswa mengalami atau memperoleh pembelajaran bahasa sebaik-baiknya. Dengan demikian, terdapat keseimbangan silabus yang disusun dari perpaduan pendekatan desain silabus yang ada sehingga silabus yang disusun bersifat multidimensional.

Sedangkan untuk desain pengembangan silabus tetap harus memperhatikan aspek dimensi seperti yang disarankan oleh Dubin dan Olshtain (1994:45--50) yaitu dimensi konten bahasa, dimensi proses, dan dimensi produk. Untuk menentukan format kolom peneliti melakukan small group discussion dengan kelima teman sejawat pada tanggal 7 Mei 2014 dengan hasil sebagai berikut.

Pada tahap awal penyusunan silabus prapengembangan, peneliti tetap menggunakan format yang telah digunakan di Politeknik Negeri Media Kreatif sejak 2009. Format kolom silabus yang digunakan di PoliMedia terdiri dari Kompetensi Inti, Kompetensi Dasar, Materi, Metode Pembelajaran, Indikator Pencapaian, dan Penilaian. Berikut adalah Prototipe I silabus bahasa Inggris untuk Semester I, II, III, dan IV.

Terhadap hasil penyajian silabus pada Prototipe I, peneliti melakukan kegiatan Peer Review 1 dengan melibatkan 5 (lima) teman sejawat, dosen bahasa Inggris yang telah bersedia membaca dan mempelajari Prototipe I di atas.
Berikut masukan dari kegiatan Peer Review 1.

(a) Rincikan lagi kolom Kompetensi Inti yang ingin dicapai.

(b) Masukkan Kode Mata Kuliah.

(c) Metode pembelajarannya sebaiknya tidak disamakan di semua pertemuan.

(d) Rincikan lagi kolom Materi Perkuliahan perminggunya.

(e) Tambahkan sumber/daftar bacaan pada Prototipe I.

(f) Ganti Format Penilaian. Tidak menggunakan nilai rata-rata $6,25 \%$ perpertemuan tetapi disesuaikan dengan format penilaian yang berlaku di PoliMedia.

\section{Prototipe II}

Berdasarkan hasil Peer Review 1, peneliti memperbaiki format dan isian Prototipe I. Selanjutnya, hasil perbaikan silabus tersebut disebut Prototipe II. Tabel 4.19 s.d. Tabel 4.22 adalah hasil penyusunan silabus untuk semester I, II, III, dan IV pada Prototipe II.

Kemudian, peneliti melakukan kegiatan Peer Review 2, yaitu dengan melibatkan tiga orang teman sejawat untuk memberikan masukan terhadap hasil Prototipe II. Selain Peer Review 2, peneliti juga mengajukan Expert Review, yaitu dengan meminta masukan dari tiga orang praktisi bidang penerbitan guna memperbaiki Prototipe II ini. Berikut rangkuman masukan/saran perbaikan dari keenam narasumber yang peneliti dapatkan.
(1) Menurut teman sejawat, walaupun materinya sudah 
diupdate tetapi detail materi belum terlihat. Tampilan silabus pada Prototipe II masih kurang rapi, masih banyak repetisi. Bagian Teaching Methodology dan Value Indicators hanya mengulang-ulang saja. Bagian itu sebaiknya digabung dan dijabarkan tersendiri.

(2) Menurut Ibu Redjeki Agoestyowati, format kolom pada silabus Prototipe II tidak efisien dan kurang informatif. Formatnya sebaiknya dibuat seperti SOP, dapat dimulai dengan identitas mata kuliah. Selanjutnya berturut-turut dapat disampaikan deskripsi mata kuliah, kompetensi yang dikembangkan, indikator pencapaian kompetensi, sumber bacaan, penilaian, dan skema perkuliahan.

(3) Menurut Bapak Dion Sitanggang dan Ibu Fariah, lebih baik penjelasan tentang silabus ini disampaikan dalam bahasa Indonesia agar mahasiswa dapat dengan cepat memahami silabus tersebut.

(4) Ketiga praktisi sependapat bahwa Kolom Indikator Pencapaian Kompetensi (Value Indicators) sebaiknya dirincikan lagi peraspeknya, aspek kognitif, psikomotorik, dan afektifnya apa saja.

\section{Prototipe III}

Berdasarkan masukan tiga orang Praktisi Penerbitan yaitu Ibu Redjeki Agoestyaswati, Bapak Dion Sitanggang, dan Ibu Fariah, berikut adalah Deskripsi Mata Kuliah selama 4 (empat) semester pada silabus baru.

\section{Semester I}

Mata kuliah ini terdiri dari dua SKS teori yang membahas tentang kata benda, kata kerja, kata ganti orang/benda, kata sifat, dan determiners, huruf kapital dan tanda baca dalam kalimat, frase dan klausa, jenis-jenis kalimat, kalimat aktif dan pasif, kalimat langsung dan tidak langsung, kata keterangan dan kata penghubung antarkalimat dan antarparagraf, proses penulisan, jenis paragraf, paragraf persuatif, ekspositori, deskriptif, dan naratif. Dengan mengikuti mata kuliah ini diharapkan mahasiswa mampu memahami grammar dan memiliki kemampuan menulis paragraf.

\section{Semester II}

Mata kuliah ini memiliki 2 SKS yang terdiri dari 1 SKS teori dan 1 SKS praktik, yang membahas tentang praktik editing (phrases, clauses, and sentences), jenis tulisan, penulisan leaflet dan booklet, penulisan deskriptif, laporan, recount, prosedur, eksplanasi, eksposisi, naskah drama, dan praktik drama. Dengan mengikuti mata kuliah ini diharapkan mahasiswa mampu memahami teknik penulisan dan penyuntingan.

Semester III

Mata kuliah ini terdiri dari dua SKS (1 SKS teori dan 1 SKS praktik) yang membahas tentang 
struktur organisasi dan deskripsi kerja tiap organ pada perusahaan penerbitan, berbagai jenis tulisan, di antaranya teks berita, cerita pendek, dan resensi film/buku/musik, rubrik pada majalah, penyuntingan, dan presentasi produk penerbitan. Dengan mengikuti mata kuliah ini diharapkan mahasiswa mampu memahami berbagai macam jenis tulisan yang terlihat dalam kemampuan berbicara, menulis, menyunting, mendengarkan, menerjemahkan, dan mempresentasikan.

Semester IV

Mata kuliah ini terdiri dari dua SKS praktik yang membahas tentang bahasa Inggris untuk bisnis, etika dalam berbisnis, peraturan dan prosedur dalam bekerja, surat-menyurat dalam bisnis, karier di bidang penerbitan, menulis lamaran dan daftar riwayat hidup yang kreatif, dan praktik wawancara pekerjaan. Dengan mengikuti mata kuliah ini diharapkan mahasiswa mampu memahami hal-hal tersebut di atas sebagai persiapan mahasiswa memasuki dunia kerja.

Selanjutnya masukan dari hasil Peer Review 2 dan Expert Review peneliti gunakan untuk melengkapi silabus bahasa Inggris. Hasil revisi tersebut dinamakan Prototipe III.

\section{Uji Lapangan Terbatas dengan Prototipe III}

Untuk tujuan uji lapangan terbatas dengan silabus bahasa
Inggris yang baru, peneliti menggunakan dua cara, pertama uji lapangan untuk dosen bahasa Inggris dan kedua uji lapangan dengan satu kali tatap muka pembelajaran dengan silabus Prototipe III ini.

a. Uji Lapangan untuk Dosen Bahasa Inggris

Uji lapangan untuk dosen bahasa Inggris ini bertujuan melihat sejauh mana dosen dapat menggunakan silabus yang baru. Langkah uji lapangannya adalah (1) dosen memilih satu materi pembahasan secara random, (2) dosen membuat rencana pelaksanaan pembelajaran (RPP) dengan materi yang telah dipilihnya, (3) peneliti mewawancarai proses dosen menurunkan silabus ke dalam RPP. Dalam penelitian ini, dosen yang bersedia melakukan uji lapangan adalah Ibu Herlinda Simanjuntak dengan materi yang dipilihnya adalah Preparing for $a$ Job Interview.

Berdasarkan proses penyusunan RPP di atas, Ibu Herlinda Simanjuntak menyatakan bahwa silabus bahasa Inggris yang baru lebih informatif dan aplikatif. Dimensi konten bahasa, proses, dan produk pada silabus yang baru dapat diaplikasikan ke RPP tersebut. Materi pembelajaran yang dipilih rata-rata sangat berguna bagi mahasiswa, khususnya mahasiswa Program Studi Penerbitan, PoliMedia. Bahasa yang digunakan dalam penyusunan 
silabus tersebut juga mudah dipahami oleh dosen sehingga memudahkan dosen menurunkan silabus tersebut ke dalam bentuk RPP dan modul ajar.

b. Uji Lapangan untuk Mahasiswa

Uji lapangan terbatas untuk mahasiswa digunakan untuk mendapatkan gambaran validitas silabus bahasa Inggris yang baru. Uji lapangan terbatas ini dilakukan dengan melibatkan 25 mahasiswa dalam satu kelas, dengan materi uji Preparing for a Job Interview. Berikut tahapan uji lapangan terbatas. Kegiatan dosen mengajar pada aspek mendengarkan dengan tema preparing for a job interview ialah (1) menjelaskan KD yakni mahasiswa mampu menjawab pertanyaan pada saat wawancara pekerjaan, (2) meminta mahasiswa membuka modul tentang wawancara pekerjaan, (3) dosen menjelaskan tentang $\mathrm{Job}$ Interview Preparation, Most Frequently Asked Interview Questions, How to Answer the Four Most Common Interview Questions, Sample Interview Questions with Suggesteed Ways of Answering, Interview Questions Practice, dan Quick GuideSample Job Interview Questions, (4) memberikan tips menjawab pertanyaan wawancara, (5) memberi praktik simulasi wawancara pekerjaan, (6) memberikan feedback masingmasing. Setelah diujicobakan, peneliti memberikan angket kepada mahasiswa tentang pelaksanaan ujicoba penggunaan silabus bahasa Inggris yang baru tersebut. Tanggapan mahasiswa, $88 \%$ senang mendapatkan materi Preparing for an Interview dan mereka tertarik untuk memahaminya lebih dalam lagi. Semua mahasiswa menyatakan bahwa mereka mandapatkan keempat aspek berbahasa pada tahap ujicoba tersebut.

Terkait proses pembelajarannya, $76 \%$ mahasiswa menyatakan bahwa kegiatan berpusat pada mahasiswa. Selanjutnya, 22 mahasiswa (88\%) menyatakan dosen membangun interaksi dengan mahasiswa dan interaksi antarmahasiswa serta memberikan feedback yang mudah mereka pahami. Sedang berdasarkan observasi di kelas, mahasiswa terlihat antusias mendapatkan materi tersebut. Mereka senang dengan pemberian games dan simulasi wawancara pekerjaan yang diberikan oleh dosen.

\section{Uji Validitas dan Uji Kelayakan Silabus Prototipe III}

Setelah Prototipe II diperbaiki sesuai dengan saran dan masukan para narasumber, Ibu Redjeki Agoestyaswati, Bapak Dion Sitanggang, dan Ibu Fariah menyatakan bahwa Prototipe III ini merupakan silabus bahasa Inggris yang telah disusun dengan baik, telah disesuaikan dengan kebutuhan mahasiswa, dosen, dan praktisi 
bidang penerbitan. Untuk itu, silabus yang baru ini valid dan layak untuk dipergunakan, dengan 3 (tiga) alasan mendasar.

a. Dimensi Isi

Dimensi Isi meliputi Deskripsi Mata Kuliah, Kompetensi yang Diharapkan, Indikator Pencapaian Kompetensi, Kompetensi Dasar, dan Materi Perkuliahan. Untuk materi perkuliahan bahasa Inggris selama 4 (empat) semester, berikut ringkasannya.

Semester I

Kata benda, kata kerja, kata ganti orang/benda, kata sifat, dan determiner, huruf kapital dan tanda baca dalam kalimat, frase dan klausa, jenis-jenis kalimat, kalimat aktif dan pasif, kalimat langsung dan tidak langsung, kata keterangan dan kata penghubung antarkalimat dan antarparagraf, proses penulisan, jenis paragraf, paragraf persuatif, ekspositori, deskriptif, dan naratif Semester II: Praktik editing (phrases, clauses, and sentences), jenis tulisan, penulisan leaflet dan booklet, penulisan deskriptif, laporan, recount, prosedur, eksplanasi, eksposisi, naskah drama, dan praktik drama.

Semester III: Struktur organisasi dan deskripsi kerja tiap organ pada perusahaan penerbitan, berbagai jenis tulisan, di antaranya teks berita, cerita pendek, dan resensi film/buku/musik, rubrik pada majalah, penyuntingan, dan presentasi produk penerbitan.

Semester IV: Bahasa Inggris untuk bisnis, etika dalam berbisnis, peraturan dan prosedur dalam bekerja, surat-menyurat dalam bisnis, karier di bidang penerbitan, menulis lamaran dan daftar riwayat hidup yang kreatif, dan praktik wawancara pekerjaan. Dilihat dari konten bahasa Inggris pada silabus yang baru sebagaimana terangkum di atas, silabus ini sudah memenuhi kebutuhan mahasiswa, dosen, dan dunia indutri.

b. Dimensi Proses

Para pakar yang menelaah silabus bahasa Inggris ini sependapat bahwa dimensi proses pada silabus bahasa Inggris yang baru sudah memenuhi kebutuhan mahasiswa, dosen, dan dunia industri. Dimensi proses tersebut ditunjukkan pada format kolom Strategi Perkuliahan. Dimensi proses yang bertumpu pada dosen antara lain ceramah, tanyajawab, dan pemberian feedback. Sedangkan dimensi proses yang bertumpu pada mahasiswa antara lain praktik membaca, menulis, menyunting, bermain peran, berpresentasi, bertanya, menjawab, memberi respon, dan sebagainya.

c. Dimensi Produk

Dimensi produk merupakan gambaran output apa yang didapat setelah mempelajari suatu materi. Sebagaimana dikemukakan pada Bab III, 
dalam pendidikan di politeknik, dimensi produk harus ditonjolkan. Dimensi produk dalam silabus prototipe III dapat terlihat di format penilaian. Sebagai gambaran dimensi produk akhir pada silabus prototipe III, untuk semester I, mahasiswa menghasilkan leaflet dan booklet, semester II mereka mampu menulis naskah drama dan memraktikkannya. Sedangkan pada semester III, mahasiswa menyusun majalah berbahasa Inggris. Untuk semester IV, mereka sudah mampu membuat surat lamaran kerja dan CV yang baik serta menguasai teknik wawancara pekerjaan dalam bahasa Inggris.

\section{PENUTUP}

Berdasarkan hasil penelitian
dan pengembangan serta
pembahasannya, dapat dikemukakan
hal-hal sebagai berikut. Pertama,
silabus mata kuliah bahasa Inggris
berdasarkan pada silabus campuran
dengan format yang mencakup
delapan komponen, yaitu identity,
standard competencies,
competencies to be achieved,
subjects, teaching methodology,
value indicator, scores, dan
references. Dari hasil studi dokumen,
terlihat bahwa penamaan mata kuliah
bahasa Inggris selama 4 (empat)
semester tersebut menggunakan
istilah Bahasa Inggris 1,2 , 3, dan 4.
Hal ini belum sesuai dengan aturan
yang telah ditetapkan oleh Direktur
Jendral Pendidikan Tinggi.

Selanjutnya mengenai jumlah materi pembelajaran, hanya ada 14 minggu. Sebaiknya disesuaikan menjadi 16 minggu. Materi pada semester III dan IV tingkatan terlalu sulit untuk level politeknik.

Kedua, temuan pada analisis kebutuhan dari hasil wawancara dan angket tertulis terhadap mahasiswa, diketahui bahwa mahasiswa merasa materi pada silabus sekarang cukup sulit untuk mereka ikuti, materinya terlalu tinggi, kurang informatif, dan sulit diaplikasikan. Sedangkan berdasarkan data angket terhadap dosen, mereka sependapat bahwa silabus yang sedang berjalan perlu diupdate sesuai dengan kebutuhan sekarang, mengingat silabus ini sudah 5 (lima) tahun digunakan. Selanjutnya, berdasarkan hasil analisis kebutuhan industri, materi yang perlu diajarkan untuk mahasiswa Program Studi Penerbitan antara lain menulis surat menyurat, di dalamnya surat lamaran dan $\mathrm{CV}$, menulis dan menyunting teks dalam bahasa Inggris, mahir dalam menggunakan tanda baca dan huruf kapital, dan fasih dalam percakapan sehari-hari dan percakapan dalam berbisnis.

Ketiga, secara teoritis, penyusunan silabus pada perguruan tinggi saat ini harus berdasarkan Kualifikasi Kerja Nasional Indonesia (KKNI). Dikarenakan belum adanya KKNI Bidang Penerbitan di Indonesia, maka dalam penelitian ini, peneliti tidak menjelaskan tentang silabus teoretis yang berkembang dewasa ini. Keempat, penyusunan 
dan pengembangan silabus bahasa pada studi dokumen, observasi pembelajaran dengan silabus berjalan, dan analisis kebutuhan mahasiswa, dosen, dan dunia industri. Pengembangannya dilakukan dengan menyusun Prototipe I, II, dan III. Prototipe I dikembangkan menjadi Prototipe II dengan metode peer review. Sedangkan Prototipe II dikembangkan menjadi Prototipe III dengan metode peer review dan expert review.

Kelima, terkait dengan uji validits oleh pakar, silabus pada Prototipe III dinyatakan valid oleh ketiga pakar yang berperan serta dalam penelitian ini. Unsur validitasnya dinyatakan karena silabus Prototipe III telah mencakup dimensi konten bahasa, dimensi proses, dan dimensi produk yang terukur. Keenam, silabus pada Prototipe III diujicobakan kepada dosen bahasa Inggris dan diaplikasikan dalam satu kali tatap muka di kelas. Respon positif dari responden dosen dan mahasiswa menunjukkan silabus yang baru ini diterima. Ketujuh, setelah di uji tingkat validitasnya dan telah diujicobakan, silabus pada Prototipe III ini, oleh para pakar dinyatakan layak untuk digunakan.

Dari butir-butir yang dikemukakan di atas dapat ditarik kesimpulan secara menyeluruh yaitu silabus yang dikembangkan (Prototipe III) ini merupakan silabus yang mempertimbangkan analisis kebutuhan (need assessment) pihak
Inggris didasarkan atas hasil temuan pengguna dan teori-teori terkait yang relevan serta mengikuti langkahlangkah prosedural secara ilmiah seperti yang dituntut dalam penelitian pengembangan. Dengan demikian, silabus yang dikembangkan ini adalah silabus yang layak karena telah memenuhi kriteria keilmiahan baik dari aspek isi maupun metodologis. Selain itu, dapat dikemukakan bahwa silabus yang sesuai dengan kebutuhan pengguna ialah silabus campuran. Sementara itu, silabus yang sedang berjalan kurang sesuai dengan kebutuhan di lapangan.

\section{DAFTAR RUJUKAN}

Brown, H. Douglas. Teaching by Principles: an Interactive Approach to Language Pedagogy. Upper Saddle River, New Jersey: PrenticeHall, Inc., 2005

Cunningsworth, Alan. Choosing Your Coursebook. Oxford: Heinemann Publishers Ltd., 1995.

Furey, Patricia R. "Considerations in the Assessment of Language Syllabuses," Trends in Language Syllabus Design, ed. John A.S Read. Singapore: Singapore University Press, 1983.

Harmer, Jeremy. The Practice of English Language Teaching. Harlow Essex: Pearson Education Limited, 2011.

Munby, John. Communicative Syllabus Design: A 
Sociolinguistic Model for

Defining the Content of

Purpose-Specific Language

Programmes. Cambridge:

Cambridge University Press, 1981.

Nunan, David. Designing Task for the Communicative Classroom. Cambridge: Cambridge University Press, 1989.

Nurhayati. Pengembangan Silabus

Pembelajaran

Bahasa

Indonesia Untuk Sekolah

Menengah Pertama Di Kota

Palembang. Program Studi
Bahasa dan Sastra Indonesia, Jurusan Pendnidikan Bahasa dan Sastra, Universitas Sriwijaya (Tesis)

Van den Akker J. Principles and Methods of Development Research. Pada J. van den Akker, R.Branch, K. Gustafson, Nieven, dan T. Plomp (eds), Design Approaches and Tools in Education and Training (pp. 114). Dortrech: Kluwer Academic Publishers. 2009 